УДК 008(371.38)

\title{
Game as a Means to Fulfill the Creative Potential of Children and Young People
}

\author{
Olesya A. Golosova* \\ Khabarovsk State Institute of Culture \\ 112 Krasnorechenskaia Str., Khabarovsk, 680045, Russia
}

Received 12.02.2016, received in revised form 18.03.2016, accepted 17.05.2016

The article is devoted to the issues of development of the game culture of celebrations and game technologies in the work with university and school students. The author reveals the major objectives and functions of game, underlines the importance of game in a child and young man's life. For students the formation of knowledge and skills in the theory and practice of game culture of celebrations, understanding the specifics features of space and time of play activity in celebratory forms of culture, the study of basic and conceptual approaches to the issues of game technologies and immediate focus on solving practical problems in this area are very important.

Keywords: game, game culture, festival, game technology, play activity.

DOI: 10.17516/1997-1370-2016-9-6-1458-1465.

Research area: culture studies.

One of the most important concepts in contemporary cultural studies is the game culture of celebration, which is included in ludology (the area of scientific knowledge about the phenomenon of "game") and reflects the objective and subjective parameters of human life. Objectively - it is the game sphere of a celebration (semantics, semiotics, symbolism of the game culture of festival) and the forms of festive and play activity (performance, carnival, rites and rituals, etc.), and professional culture of experts-directors of a festival. Subjectively the game culture is revealed in the skills and abilities of the person's play (creative) behavior.
In the applied and practical sense the game culture of festival is a creative, theatrical and project activity to create various celebratory game forms on the basis of game technology.

Public celebration is a special, multifaceted social phenomenon that reflects the life of every person and the society as a whole. Even on the basis on its prevalence among all the peoples of the world without exception, it is possible to judge about the enduring value of celebrations for an individual and society. The deep roots of celebrations that go to the era of the mankind's "childhood", evidence that they are one of the oldest and primary forms of the human culture. In the celebrations the rest has always the meaning of

(C) Siberian Federal University. All rights reserved

* Corresponding author E-mail address: olesya_golosova@mail.ru 
a public act. Many restrictions weaken or become invalid. During these days people become the equal participants of public actions, feasts and carnival fun that merge the real and the ideal, life and play. Any public celebration includes a ludic element.

Therefore, for the students who study at the specialization of "Stage Shows and Celebrations Direction", for the formation of future skills it is very important to know and understand the specific features of the play activity. Formation of knowledge and skills in the field of theory and practice of game culture of celebrations, understanding the specific features of time and space of play activity in celebratory forms of culture, the study of basic and conceptual approaches to the ussies of game technology and immediate focus on solving practical problems in this area will contribute to the becoming of the future specialist-director for the sphere of culture and art.

Game is the form of person's free expression that suggests a real openness to the world of the possible and is expressed either as a competition or as a representation of any situations, meanings and conditions. Modern culturological idea represents the game as an independent field of study and substantiates the through value of the game in the development of major cultural forms of human activity: art, science, philosophy, politics, etc. (Hejzinga, 2002).

The game is a form of activity in conventional situations, aimed at the reconstruction and adoption of social experience, embodied in socially established methods of making an object action, in the subjects of science and culture. In the game, as a specific historically arisen kind of social practice, the norms of human life and activity are reproduced, and following these norms ensures cognition and adoption of the subject and the social reality, as well as intellectual, emotional and moral development of an individual. The game is an area where the preparation of the younger generation for life takes place, and therefore, ideological function is carried out (Igrovaia deiatel'nost', 2006).

The game belongs to the basic types of human activities, along with leaning and labor. It has a centuries-long history and, having appeared in the life of the ancient man it is considered unsolved up to the present. The elements of the game present in a person's life at its any stage from the early childhood to the end of his days. Socio-cultural role of the game is particularly evident at the early stages of human development. The most important skills of human life in the archaic society were mastered in the game imitation, the knowledge about the natural and cultural world were transferred and solidified. Games were used for the socialization of the younger generation (especially as part of the initiation rite), for the preparation for the collective hunt, for training and for the communicative interaction development. The very principle of the game imitation embodies the dichotomy of normative and creative. The game is characterized by the highest strain of man's personal powers, experience, emotional and sensual intensity, aesthetic significance and attractiveness (Savelova, 2013).

In human practice play activity performs the following functions:

- entertaining (the main function of the game is to entertain, to give pleasure, to inspire, to spark interest);

- self-realization;

- therapeutic: overcoming various difficulties that appear in other forms of life activities;

- diagnostic: identifying deviations from the standard of conduct, self-knowledge in the course of the game;

correctional function: making positive changes to the structure of personal performance; 

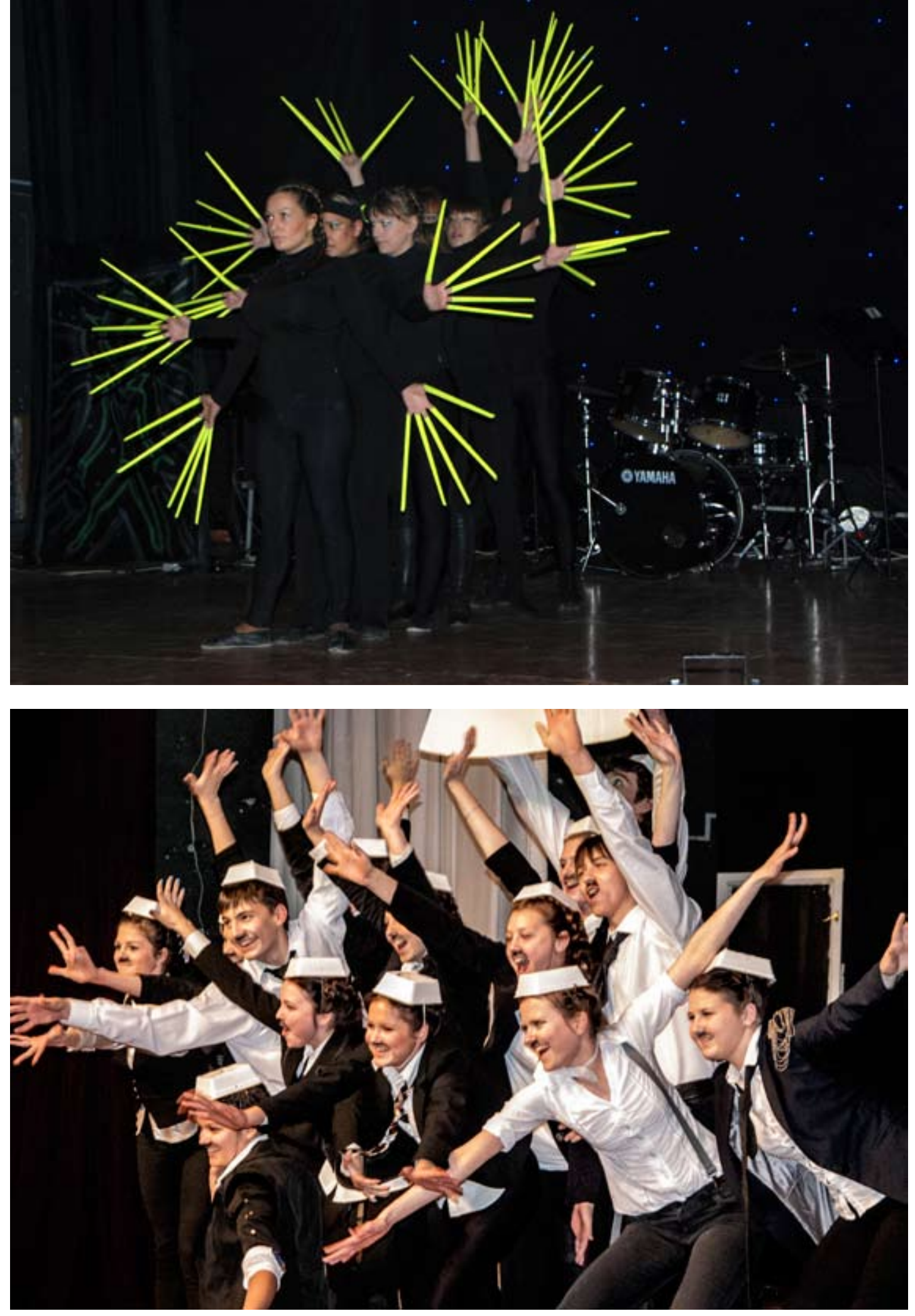
- international communication: adoption of social and cultural values common to all people;

- socialization: inclusion to the system of social relations, adoption the norms of human coexistence.

- communicative: mastering the dialectics of communication.

Game is a special method of processing the impressions received from the world around us, accessible and attractive kind of activity not only for children but also for teenagers and young people, including students. The peculiarities of student's thinking and imagination, their emotionality, activity and growing need for communication are especially manifested in the game. The interest in the game increases student's mental activity, and he/she can solve a more difficult problem than at a usual lesson. But this does not mean that lessons should be given only in the form of games. The game is only one of the methods and it gives good results only in combination with such ways of mastering the material as observation, conversation, reading, etc. (Usova, 1999).

During the game, students learn to apply their knowledge and skills in practice, to use them in different circumstances. The game is mostly independent activity, which is based on communication with peers. They are united by a common goal, collaborative efforts to its achievement and common experience. Game experiences leave a deep impression in consciousness and contribute to the formation of, as a rule, positive emotions, good feelings, noble aspirations, skills of collective life and healthy competition.

Creative games occupy an important place in the system of physical, moral, labor and aesthetic education. A teenager and a young man need vigorous activity that contributes to the increase of their vital tonus, satisfying their interests and social needs. The game is of great educational value, it is closely connected with education in the classroom, with observations of everyday life. Students learn to solve their game tasks independently, to find the best way to implement his plans, to use their knowledge and express them verbally. Quite often the game is the cause for telling new knowledge, to expand the horizons.

The natural tendency of children, as well as teenagers and young people to game is successfully used in teaching practice. The specific content and forms of the process of game are very diverse and are determined by a number of factors. It is believed that most of the games have the following main features:

- free developing activity, undertaken only at the request, for the pleasure from the process of the activity, but not only from and for the result;

- creative, improvisational, active in its nature activity;

- emotionally tense, elevated, adversary and competitive activity;

- activity that takes place in the framework of direct or indirect rules, reflecting the content of the game;

- activity that has imitational character;

- activity, detached from the "everyday" life by the place of action - acting area and duration. The game is not "everyday" life and life as such. It is rather a way out of the framework of this life into a temporary sphere of activity that has its own orientation. It is "played out" within the certain framework of space and time. There is unconditional order within the game space;

- the availability of a minimum game situation.

The game only superficially seems carefree and easy. In fact, it imperiously demands the player to give it the most of his/her energy, intelligence, endurance and self-sufficiency. The connection of game with training and leisure at the same time is determined by its ability to create 
conflicts, which solution in the practical sphere of activity is either difficult or impossible. That is why the game is not only a physical training, but also a means of psychological preparation for the future life situations, a certain model of conflict.

The structure of the game as an activity naturally includes goal-setting, planning and goal achievement, as well as analysis of the results, where an individual completely fulfils him/ herself as a person. Motivation of play activity is provided by its voluntariness, possibilities of choice and elements of competition, meeting its needs in self-affirmation and self-actualization (D.B. El'konin, 1977).

The structure of the game as the process includes: a) roles taken by the players; b) game activities as a means of these roles implementation; c) game use of the objects, i.e. replacing real things with the game ones, conditional; g) real relationships between the players; d) the plot (content) is the area of reality, conventionally reproduced in the game.

A peculiarity of the modern existence of games and play activity is a complex correlation of active and passive games (in particular, computer games). A special place belongs to TV games that might be in the category of passive games, if their viewing didn't result into any effective reaction; or in the category of active games if they become a model activating the viewers' actions. Of course, in the passive case the trace remains (memory, experienced emotions, the information obtained as a result of the transfer). But the passive experiences that were not embodied in real action are erased by the subsequent ones, and thus they are leveled.

It is a passive life position of students that cause anxiety of teachers and professionals who work with young people. But to a large extend it depends on the passivity of the teachers, lecturers and youth organizers.
Game activity is in demand and attracts young people because of the possibility of selfactualization (Bestuzhev-Lada, 1984). Game activities, including TV programs that are devoted to games, do not themselves have a negative basis: much depends on who and how makes these programs, what values they bring to the youth and teenage audience. The proof of this is the history of KVN that ceased to exist in the Soviet period due to the political acuteness, expression of public positions and new aspirations of the youth. According to its creators and the first participants' memories, there was much less vulgarity and bad taste, which are sometimes demonstrated by the modern games and thrashprograms.

The striving of teenagers and young people to self-realization is embodied in the game activities, in KVN teams and in the games that take place during the summer holidays of university and school students. In the course of the game young people's personal qualities change. Long-term observations show that coming to the team with the lack of confidence, inhibited and psychologically closed, the teenagers disclose, they manifest abilities and talents (acting, directing, script writers abilities), as well as organizational skills. The analysis of the survey results conducted among the participants of KVN teams to study the social portrait of young people, shows that this group is socially active, adapted, goal-oriented and relies on their strength.

From all this we can conclude that young people actively use different game technologies at their leisure time (Kjendo, 2000).

Perhaps in order to increase the number of young people, who include game technologies to their leisure activities, it is necessary:

- to have thematic games during public holidays;

- actively promote various game clubs; 
- to have games in the Houses of Culture, cultural and entertainment centers, etc.

In the process of education such forms of activities that ensure the active participation of each student, increase the authority of knowledge and individual responsibility for the results of educational labor, occupy a special place. These objectives can be successfully met through the technology of the game forms of education.

In the statements of the great teachers K.D. Ushinsky and A.S. Makarenko creative play is regarded as an independent activity in which children most fully reveal their identities and "shape" personality. "A good game is like a good job, they are united by the force of thought and work effort, the joy of creativity and a sense of responsibility" (Makarenko, 1951). An eminent researcher of game D.B. El'konin believes that "the game is social in its nature and direct saturation and is projected on the reflection of the world of adults." Calling the game "the arithmetic of social relations", D.B. El'konin interprets the game as "an activity that appears at a certain stage as one of the leading forms of mental functions development and ways of child's understanding the world of adult" (D.B. El'konin, 1977).

There is a classification of games that develop intelligence and cognitive activity. Using all the five types of play activities in his work the teacher has a huge arsenal of the ways to organize educational and cognitive activity of students.

1) The object games as the manipulation with toys and objects. Through toys and objects children learn the shape, color, size, material, the world of animals, the world of people, etc.

2) Creative games and socio-dramatic plays where the plot is a form of intellectual activity.

3) Games with the already established rules that are usually called didactic games.

4) Construction, labor, engineering and design games. These games represent the professional activities of adults.
5) Games-exercises and games-trainings that influence mental sphere. Based on the competition, by comparison, they show the players the level of their readiness and proficiency, suggest ways for self-improvement, and thus encourage their cognitive activity.

Thus, the game reproduces stable and innovative in the practice of life and, therefore, is an activity in which the rules and conventions of the game reflect the stability - they have strong traditions and norms, and repetition of the game rules creates a training basis for the development of children and teenagers.

Spontaneous development of game and technical movement, which was primarily based on the use of business games that served as the basis for the development of a large group of teaching methods known as active learning methods, played a special role in the formation of the modern education through play. Theoretically, their use has been proved in several conceptions primarily in active learning theory. The first business game was designed and conducted by M.M. Birstein in the USSR in 1932. The method was picked up and immediately gained recognition and rapid development. However, in 1938, business game in the Soviet Union suffered the fate of a number of other research areas, they were banned. Their second birth took place only in the 1960s after the first business game appeared in the USA (1956, C. Abt, C. Greenblatt, F. Gray, G. Graham, G. Dupuis, R. Duke, R. Prudhomme, et al.).

Educational games occupy an important place among the modern psychological and pedagogical technologies. Today in Russia, in the United States and in other developed countries there is no institution that does not use business games or game method of teaching.

Nowadays almost every teacher uses nontraditional forms of students training in his/her work. In our opinion, it is connected with the 
emergence of a new style of pedagogical thinking of the teacher who focuses on the intense and effective solution of educational and pedagogical problems within a modest amount of subject hours to recognize the fact intensification of independent creative and exploratory activities of students, etc. (Bespal'ko, 2008).

The arsenal of the forms of the modern teacher lessons is not just renewed under the influence of the increasing role of the student's personality and is transformed in the direction of the unusual game forms of presenting the material. Therefore, the choice of the way of development in the modern period, forecasting events and phenomena, moral and ethical evaluations of individuals and the course of events are very important for the discussion and development of students' self-assessment.
Controversial nature of these issues at the lesson is impossible without gaining the experience of having a dialogue, dispute and inclusion into the creative activity.

Through the game and in the game the consciousness of a teenager and a young man gradually prepares for the upcoming changes in the living conditions, relationships with peers and with the older people, qualities of the personality needed in the future are formed. Such qualities as independence, proactiveness and self-discipline are formed in the game, creativeness and the skills for team work are developed. The game generates a considerable interest in the subject, it allows to develop individual abilities of each student, thus increasing the level of progress in studies and the development of cognitive processes among students.

\section{References}

Bespal'ko, V.P. [2008]. Slagaemye pedagogicheskoj tekhnologii [Components of Pedagogical Technology]. M., Prosveshchenie.

Bestuzhev-Lada, I.V. [1984]. Molodost' i zrelost': Razmyshlenija o nekotorykh sotsial'nyh problemakh molodezhi [Youth and Adulthood: Contemplations about Some Social Problems of Young People]. M., Politizdat.

Drobinskaia, E.I., Sokolov, E.V. [1983]. Svobodnoe vremia i razvitie lichnosti [Free Time and Personality Development]. L., 7-17.

Hejzinga, J. [2002]. Homo ludens. Chelovek igraiushchii [Homo Ludens. Playing Man]. M.: Kolos.

Igrovaia deiatel'nost' i sotsializaciia molodezhi: istoricheskie i sotsial'nye aspekty problem [Play Activity and Young People Socialization: Historic and Social Aspects of the Problem] [2006], In Prilozhenie k zhurnalu "Teoreticheskie i prikladnye problemy servisa" [Supplement to Journal "Theoretical and Applied Problems of Service”]. M., MGUS.

El'konin, D.B. [1977]. Psikhologiia igr [The Psychology of Games]. M., Vlados.

Kjendo, T. [2000]. Dosug i populiarnaia kul'tura v dinamike i razvitii [Leisure and Popular Culture and Dynamics and Development], In Lichnost'. Kul'tura. Obshchestvo. [Personality. Culture. Society.]. 1(2), 2-88.

Makarenko, A.S. [1951]. O vospitanii molodezhi: sb. izbr. ped. proizvedenii [On Young People Education: Collection of Selected Pedagogical Works]. M., Trudrezervizdat.

Savelova, E.V. [2013]. Mif, ritual i igra v kommunikativnom prostranstve kul'tury [Myth, Ritual and Game in the Communicative Space of Culture], In Uchenye zapiski Komsomol'skogo-na-Amure gosudarstvennogo tehnicheskogo universiteta. Nauki o cheloveke, obshhestve i kul'ture [Proceedings 
of Komsomolsk-on-Amur State Technical University. Sciences of Man, Society and Culture]. Komsomol'sk-na-Amure, I - 2(13), 67-75.

Tregubov, B.A. [1991]. Svobodnoe vremja molodezhi: sushchnost', tipologiia, upravlenie [Leisure Time of Young People: Essence, Typology, Management]. SPb.

Usova, A.P. [1999]. Rol' igry v organizatsii zhizni i deiatel'nosti detei [The Role of Game in Children's Life and Activities Arrangement], In Doshkol'noe vospitanie [Pre-School Education], 7.

\title{
Игра как средство реализации \\ творческого потенциала детей и молодежи
}

\section{О.А. Голосова}

Хабаровский государственный институт культурь Россия, 680045, Хабаровск, ул. Краснореченская, 112

\begin{abstract}
Статья посвящена вопросам развития игровой культуры праздников и игровых технологий в работе со студентами и школьниками. Автор раскрывает основные задачи и функиии игры, подчеркивает значение игры в жизни ребенка и молодого человека. Для студентов очень важно формирование знаний, умений и навыков в области теории и практики игровой культуры праздника, понимание специфики пространства и времени игровой деятельности в праздничных формах культуры, изучение базовых, концептуальных подходов к вопросам игровых технологий и непосредственная ориентаиия на решение практических проблем в этой области.
\end{abstract}

Ключевые слова: игра, игровая культура, праздник, игровая технология, игровая деятельность.

Научная специальность: 24.00.00 - культурология. 